\title{
An investigation of wind characteristics on the campus of Izmir Institute of Technology, Turkey
}

\author{
B. Ozerdem *, M. Turkeli \\ Department of Mechanical Engineering, Izmir Institute of Technology, Urla, Izmir 35430, Turkey
}

Received 1 June 2002; accepted 23 June 2002

\begin{abstract}
The European Wind Atlas shows a very high wind energy capacity over the Aegean Sea and its coastal regions. Therefore, the western region of Turkey, which has a long coast along the Aegean Sea, appears to have high potential of wind energy. As a result of this fact, several studies have been performed to estimate the wind potential, especially, in western Turkey. However, due to the absence of a reliable and accurate Wind Atlas of Turkey, further studies on the assessment of wind energy in Turkey are necessary. In this study, the characteristics of wind on the campus of Izmir Institute of Technology, located in Cesme peninsula which has long coastline along the Aegean Sea, were studied over a period of one year. Measured data set and its evaluation showed that Izmir Institute of Technology campus area has a considerable wind energy potential. The study presented here is an attempt to promote wind energy in Turkey and to bridge the gap in order to create prospective Turkish Wind Atlas.

(C) 2002 Elsevier Science Ltd. All rights reserved.
\end{abstract}

Keywords: Wind energy; Wind site; Wind characteristics; Wind measurement mast; Weibull parameters

\section{Introduction}

Renewable energy resources have gained great importance, due to limited fossil fuel resources and their negative environmental impacts such as air pollution, acid rain and greenhouse effects. Increased cost of conventional energy resources, also,

* Corresponding author. Tel.: +90-232-498-6519; fax: +90-232-498-6505.

E-mail address: ozerdem@likya.iyte.edu.tr (B. Ozerdem). 
have helped renewable energy resorces to receive attention from all over the world. Among many renewable energy resources, wind energy seems to be the most suitable and cost effective power source for electricity production.

Detailed knowledge of the characteristics of wind is necessary for the design of wind energy systems. This is accomplished by using wind speed measurements. But this is a very difficult task, due to transitions in direction and speed of wind at most sites. Many studies have been completed to estimate the wind potential in different parts of the world. An example of these studies is the European Wind Atlas [1]. The European Wind Atlas shows a very high wind energy capacity over the Aegean sea and its coast regions. Therefore, the western region of Turkey which has a long coast along the Aegean Sea, appears to have high potential of wind energy.

The population increase and industrialization effort have created an awareness of the renewable energy resources in Turkey. As a result, several studies have been performed to estimate the wind potential, especially, in western Turkey. The assessments of wind power are studied by Tolun et al for Gökçeada [2]; Incecik and Erdoğmus [3], and Şen and Şahin [4] for western Turkey; Türksoy [5], and Dündar and Inan [6] for Bozcaada. However, due to the absence of a reliable and accurate Wind Atlas of Turkey, further studies on the assessment of wind energy in Turkey are necessary. The present study is an attempt to bridge this gap.

\section{Materials and methods}

\subsection{Description of the site}

Izmir Institute of Technology campus, which occupies 3500 ha area, is located in a county called Urla of Izmir province. Izmir province is right by the Aegean Sea and has a hilly topography. Urla is one of the main county in Cesme peninsula. The campus includes several hills with 15-25\% incline. These hills are covered with typically Mediterranean bushes. Soil depth is very low and not suitable for vegetation. Fig. 1 shows the site on Izmir map.

\subsection{The wind data measurement mast}

Before installation of the mast, an aerial search was made by a helicopter in order to find the most appropriate site location. The site with coordinates of $465684 \mathrm{E}$ and $4243843 \mathrm{~N}$ (in UTM coordinate system) at $460 \mathrm{~m}$ height, from sea level, was found to be the most suitable mast location in the area. There were no obstacles around the measurement area. The site was directly open to the Aegean Sea at north direction. The south and northwest directions were covered with hills. The wind data measurement mast was $30 \mathrm{~m}$ tall tubular tower which was erected in July 2000. The mast is shown in Fig. 2. It had two cup anemometers which were at 10 and $30 \mathrm{~m}$ heights, and one wind vane at $30 \mathrm{~m}$ height. Temperature, relative humidity, and atmospheric pressure data were obtained from a thermometer, a hygrometer and a barometer, respectively. A data logger was connected with all sensors on the mast 


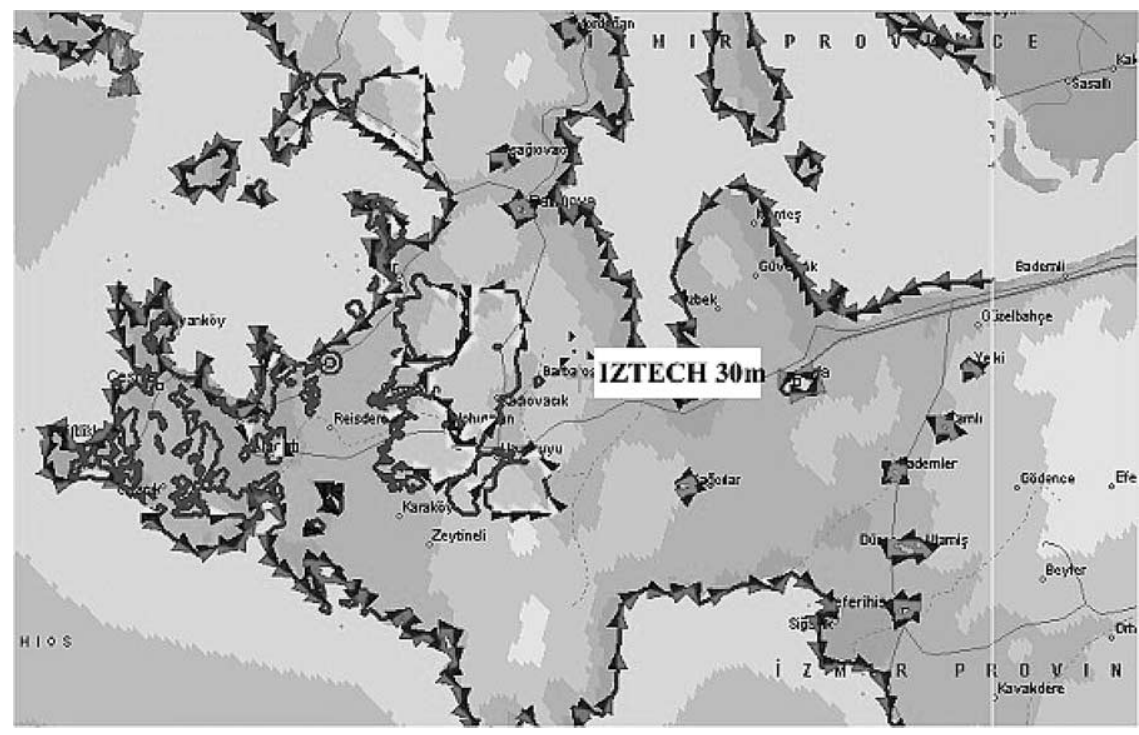

Fig. 1. Location of the site.

to collect data in time series. Power for the equipments was supplied from an external battery charged by a solar panel. The mast was, also, equipped with a GSM modem system which was used by the data logger to achieve remote data transferring. The technical specifications for the equipments are shown in Table 1.

\subsection{Data collection and evaluation}

The data were collected for 16 months between July 2000 and November 2001. In the year of 2000 the data were collected with a rate of 24 observations per day using $1 \mathrm{~h}$ time intervals . But in 2001 time interval rate was changed to 144 observations per day using 10 min time intervals. The missing data should not exceed $10 \%$ according to the standards [7]. In this study, the missing data were $3.7 \%$ in the total collected data. The time interval configuration change was done to gain more precise results. The 'CALLaLOG' software was used for remote data transfering. The 'windPRO' software played a key role to evaluate all collected data in order to make wind analysis considering orography and topography at the site.

The collected data included date and time stamp, wind direction, maximum, minimum, average and deviation values of wind speeds at 10 and $30 \mathrm{~m}$ heights of the mast, relative humidity, temperature and barometric pressure.

Commercially available 'Encarta Digital Atlas' compact disc was used for area map. Digital height counter map which covers area within $5 \mathrm{~km}$ radius and surface roughness map which covers $20 \mathrm{~km}$ radius around measurement point were created and loaded into 'WindPRo' software. There were no obstacles around measurement point in 12 sectors. 


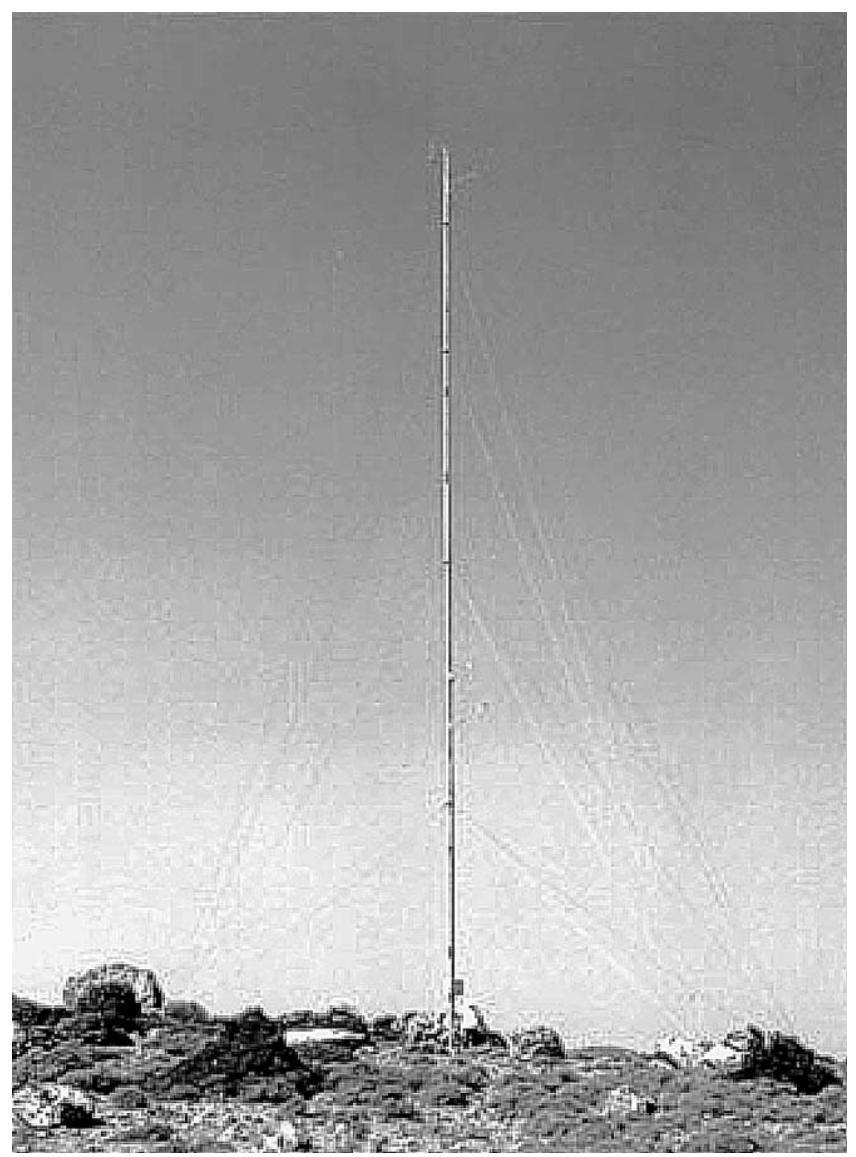

Fig. 2. Mast erected on the campus.

Table 1

Nominal specifications of the equipments

\begin{tabular}{llllll}
\hline Specification & Anemometer & Wind vane & Thermometer & Hygrometer & Barometer \\
\hline $\begin{array}{l}\text { Measurement } \\
\text { range }\end{array}$ & $0.3-50 \mathrm{~m} / \mathrm{s}$ & $0-360^{\circ}$ & $(-30)-(+70){ }^{\circ} \mathrm{C}$ & $0-100 \% \mathrm{RH}$ & $800-1600 \mathrm{hPa}$ \\
$\begin{array}{l}\text { Accuracy } \\
\text { Resolution }\end{array}$ & $\pm 2 \%$ & $\pm 2 \%$ & $\pm 2 \mathrm{~K}$ & $\pm 2 \% \mathrm{RH}$ & - \\
\hline
\end{tabular}

\section{Results and discussion}

\subsection{Analysis of atmospheric parameters}

Table 2 shows monthly averages of the temperature, relative humidity and atmospheric pressure for one year. The temperature average was $16.3^{\circ} \mathrm{C}$. The maximum 
Table 2

Monthly average values of atmospheric parameters

\begin{tabular}{lccc}
\hline Months & Relative humidity $(\%)$ & Temperature $\left({ }^{\circ} \mathrm{C}\right)$ & $\begin{array}{l}\text { Barometric pressure } \\
(\mathrm{hPa})\end{array}$ \\
\hline Jul-00 & 42 & 26.3 & 955 \\
Aug-00 & 49 & 23.2 & 957 \\
Sep-00 & 20.5 & 958 \\
Oct-00 & 56 & 14.2 & 961 \\
Nov-00 & 75 & 13.8 & 962 \\
Dec-00 & 8.2 & 967 \\
Jan-01 & 10.6 & 995 \\
Feb-01 & 82 & 10.9 & 994 \\
Mar-01 & 74 & 12.5 & 958 \\
Apr-01 & 75 & 17.2 & 974 \\
May-01 & 71 & 15.9 & 961 \\
Jun-01 & 75 & 21.9 & 960 \\
\hline
\end{tabular}

and minimum monthly average temperatures were $26.2^{\circ} \mathrm{C}$ in July 2000 and $8.2^{\circ} \mathrm{C}$ in December 2000. The atmospheric pressure average was $967 \mathrm{hPa}$. The maximum average value of $995 \mathrm{hPa}$ and minimum average value of $955 \mathrm{hPa}$ were observed, respectively, in January 2001 and in July 2000. The annual average of relative humidity was $65 \%$ with maximum value of $82 \%$ and minimum value of $42 \%$ observed, respectively, in July 2000 and December 2000.

\subsection{Wind speed analysis of monthly mean speed}

The wind speeds were measured by two anemometers located at 10 and $30 \mathrm{~m}$ height on the mast. The reason for measuring wind speeds at two different heights was to calculate wind shear value. Figs. 3 and 4 show monthly mean speed variations at 10 and $30 \mathrm{~m}$, respectively. The average speeds were $7.03 \mathrm{~m} / \mathrm{s}$ at $10 \mathrm{~m}$, and 8.14 $\mathrm{m} / \mathrm{s}$ at $30 \mathrm{~m}$. It can be noted that monthly average speeds were always higher than cut-in speeds of the most horizontal axis wind turbines.

\subsection{Wind direction analysis}

Figs. 5 and 6 show wind speed, wind direction and turbulence intensity variations for $10 \mathrm{~m}$ and $30 \mathrm{~m}$, respectively. The prevailing wind directions are north and northnortheast sectors. There were strong winds blowing from southern sectors too. But their frequencies were quite low. Weibull histograms are determined for 12 sectors at 10 and $30 \mathrm{~m}$ heights separately. Tables 3 and 4 show Weibull data, respectively, for 10 and $30 \mathrm{~m}$ heights. Histograms for each separate sector can be seen in Figs. 7 and 8 for $10 \mathrm{~m}$ measurements and in Figs. 9 and 10 for $30 \mathrm{~m}$ measurements. These figures show that 78.6 and $74.9 \%$ of the wind blew from north, respectively, at 10 and $30 \mathrm{~m}$ height. NNE sector is another main sector, but its frequencies are only 


\section{MeanSpeed of $10 \mathrm{~m}$}

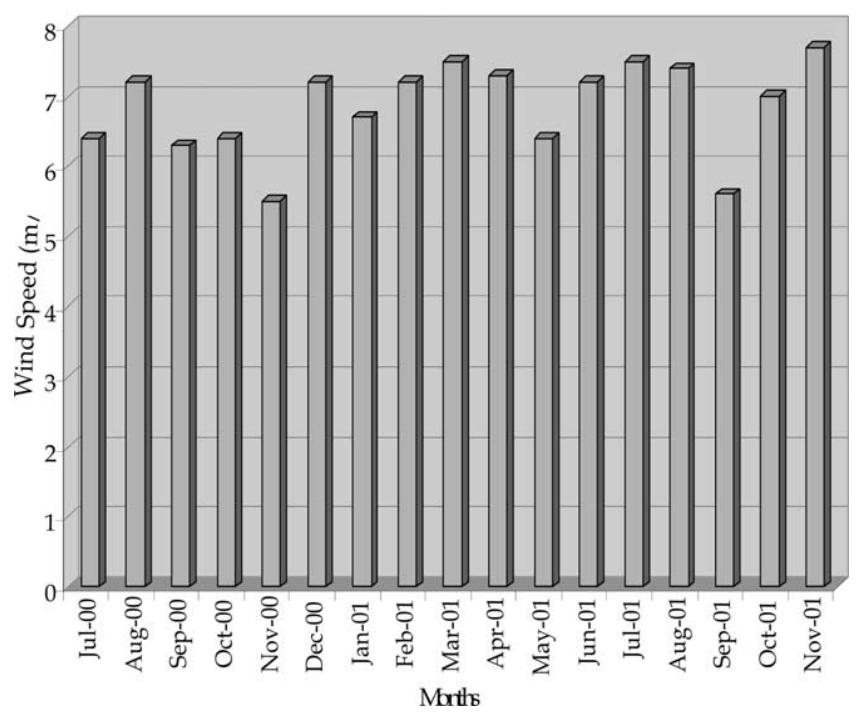

Fig. 3. Variation of monthly mean speeds at $10 \mathrm{~m}$ height.

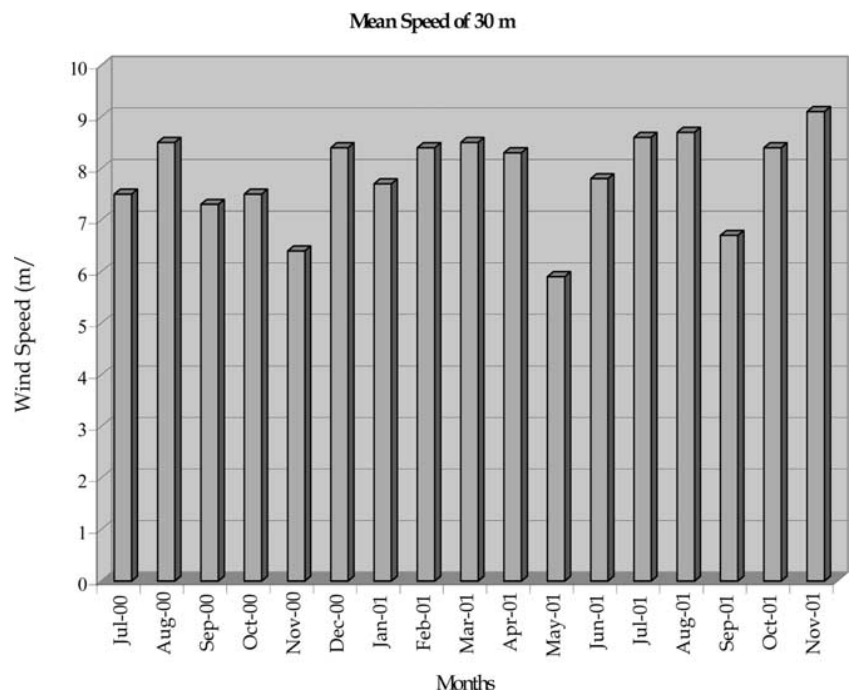

Fig. 4. Variation of monthly mean speeds at $30 \mathrm{~m}$ height.

4.7 and $5.3 \%$, respectively, for 10 and $30 \mathrm{~m}$ measurements. Frequencies for other sectors are not higher than $3.9 \%$. 

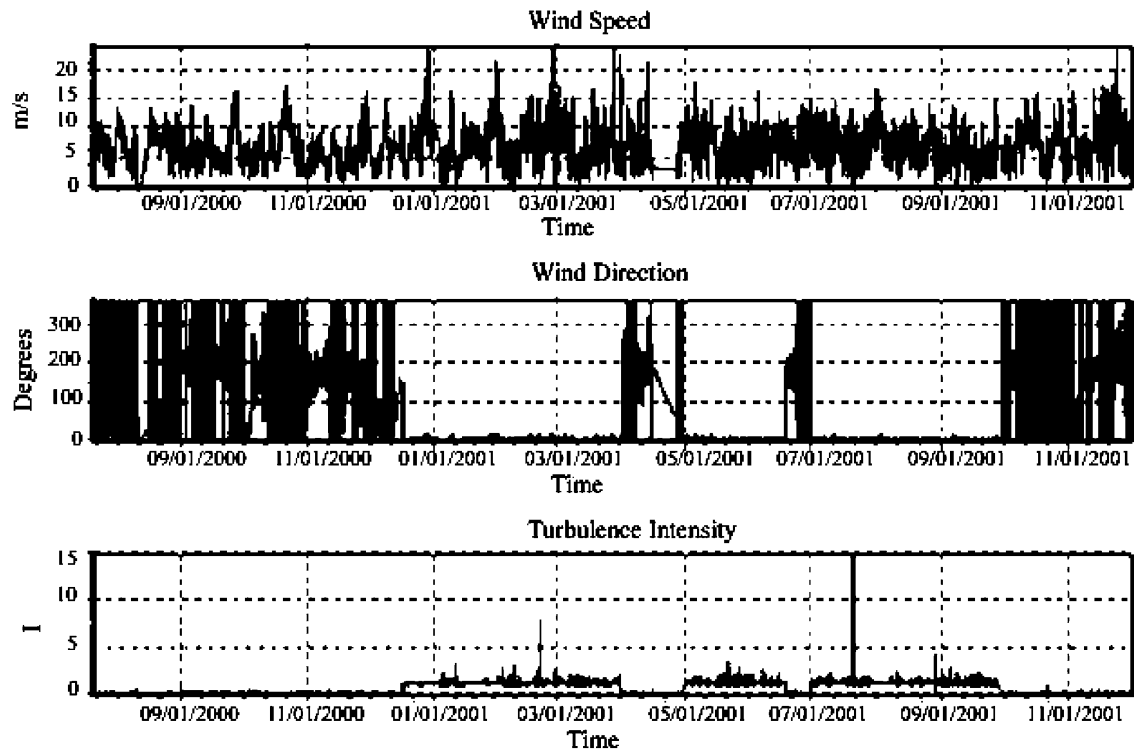

Fig. 5. Wind speed, wind direction and turbulence intensity variations at $10 \mathrm{~m}$ height.
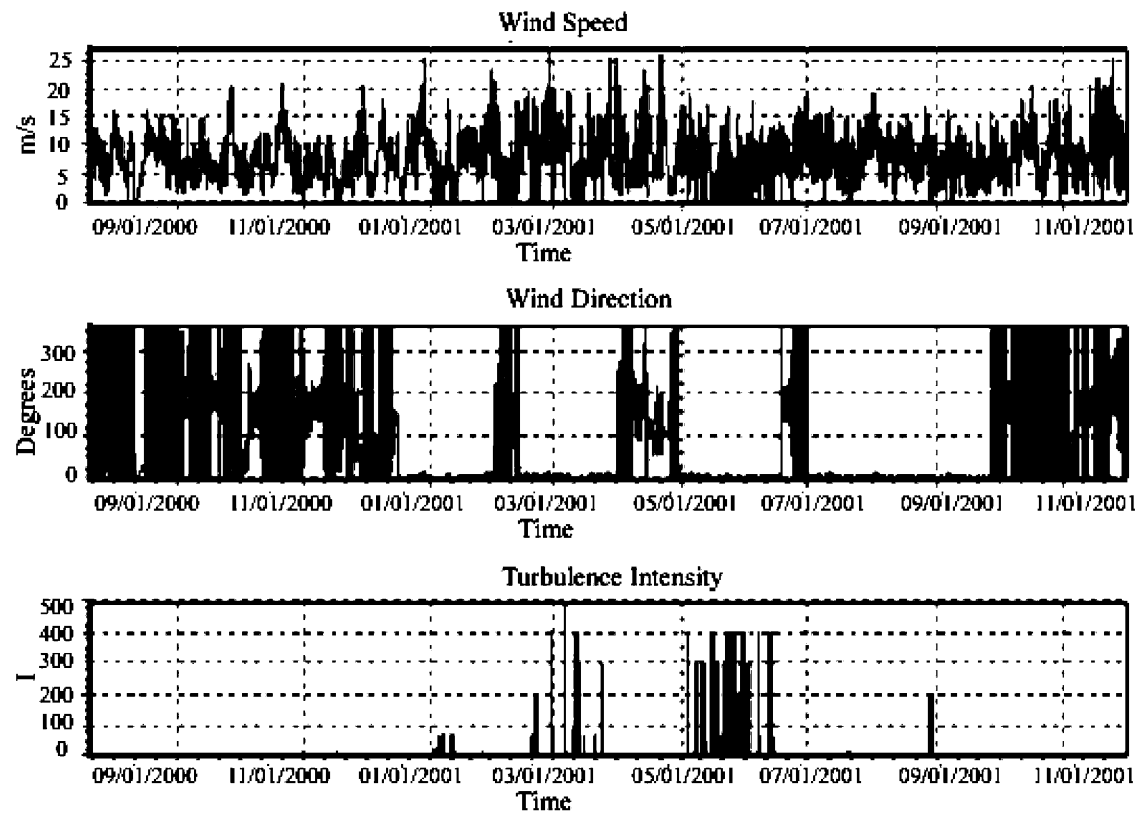

Fig. 6. Wind speed, wind direction and turbulence intensity variations at $30 \mathrm{~m}$ height. 
Table 3

Weibull parameters for 12 sectors according to measured data at $10 \mathrm{~m}$ height

\begin{tabular}{lccccc}
\hline Sector & A-parameter $(\mathrm{m} / \mathrm{s})$ & $\begin{array}{l}\text { Mean wind } \\
\text { speed }(\mathrm{m} / \mathrm{s})\end{array}$ & & Frequency & Wind shear \\
\hline N & 8.08 & 7.17 & 2.470 & 78.61 & 0.14 \\
NNE & 8.41 & 7.56 & 1.575 & 4.65 & 0.14 \\
ENE & 4.10 & 3.66 & 1.692 & 0.66 & 0.09 \\
E & 4.37 & 3.88 & 1.925 & 0.69 & 0.07 \\
ESE & 8.70 & 7.71 & 2.059 & 1.53 & 0.13 \\
SSE & 8.07 & 7.21 & 1.648 & 3.19 & 0.13 \\
S & 6.77 & 6.10 & 1.542 & 2.57 & 0.13 \\
SSW & 6.39 & 5.66 & 2.272 & 2.30 & 0.21 \\
WSW & 7.24 & 6.47 & 1.683 & 0.94 & 0.10 \\
W & 5.97 & 5.54 & 1.278 & 0.88 & 0.07 \\
WNW & 5.94 & 5.28 & 1.837 & 1.56 & 0.13 \\
NNW & 7.85 & 6.99 & 2.888 & 2.42 & 0.14 \\
Mean & 7.94 & 7.03 & 2.228 & 100.00 & \\
\hline
\end{tabular}

Table 4

Weibull parameters for 12 sectors according to measured data at $30 \mathrm{~m}$ height

\begin{tabular}{|c|c|c|c|c|c|}
\hline Sector & A-parameter $(\mathrm{m} / \mathrm{s})$ & $\begin{array}{l}\text { Mean wind } \\
\text { speed }(\mathrm{m} / \mathrm{s})\end{array}$ & k-parameter & Frequency & Wind shear \\
\hline $\mathrm{N}$ & 9.41 & 8.35 & 2.473 & 74.86 & 0.14 \\
\hline NNE & 9.77 & 8.74 & 1.633 & 5.25 & 0.13 \\
\hline ENE & 4.45 & 3.99 & 1.596 & 0.80 & 0.08 \\
\hline $\mathrm{E}$ & 4.73 & 4.20 & 1.820 & 0.81 & 0.07 \\
\hline ESE & 10.09 & 8.94 & 2.111 & 1.70 & 0.13 \\
\hline SSE & 9.31 & 8.31 & 1.693 & 3.92 & 0.13 \\
\hline S & 7.87 & 7.03 & 1.690 & 3.48 & 0.13 \\
\hline SSW & 8.08 & 7.16 & 2.052 & 2.86 & 0.21 \\
\hline WSW & 8.10 & 7.23 & 1.668 & 0.99 & 0.10 \\
\hline $\mathrm{W}$ & 6.29 & 5.88 & 1.235 & 0.92 & 0.05 \\
\hline WNW & 6.40 & 5.68 & 1.886 & 1.66 & 0.07 \\
\hline NNW & 8.99 & 8.04 & 3.082 & 2.75 & 0.13 \\
\hline Mean & 9.19 & 8.14 & 2.211 & 100.00 & 0.13 \\
\hline
\end{tabular}

\subsection{Wind turbulence analysis}

Weibull parameters listed in Tables 3 and 4 show that mean wind speeds of north sector are $7.17 \mathrm{~m} / \mathrm{s}$ at $10 \mathrm{~m}$ height and $8.35 \mathrm{~m} / \mathrm{s}$ at $30 \mathrm{~m}$ height. Shape factor $(k)$ for $30 \mathrm{~m}$ height is 2.473 which means that measured data differ from the Rayleigh distribution. Eight sectors out of 12 sectors have mean speeds higher than $7 \mathrm{~m} / \mathrm{s}$ at $30 \mathrm{~m}$ height. This is an excellent result in the name of high wind energy potential.

Turbulence intensity is very high in the north sector at $10 \mathrm{~m}$ height as shown in 

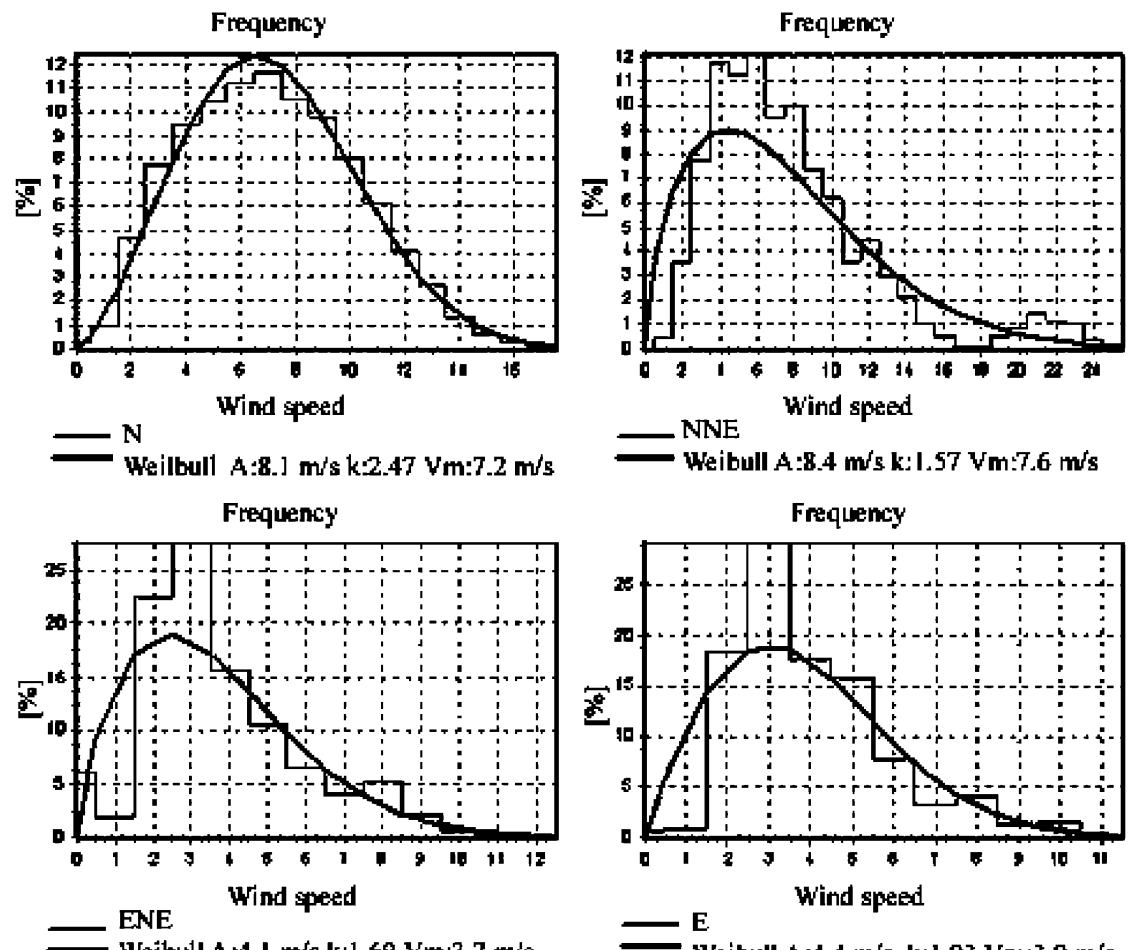

Weibull A :4. I m/s k:1.69 Vm:3.7 m/s
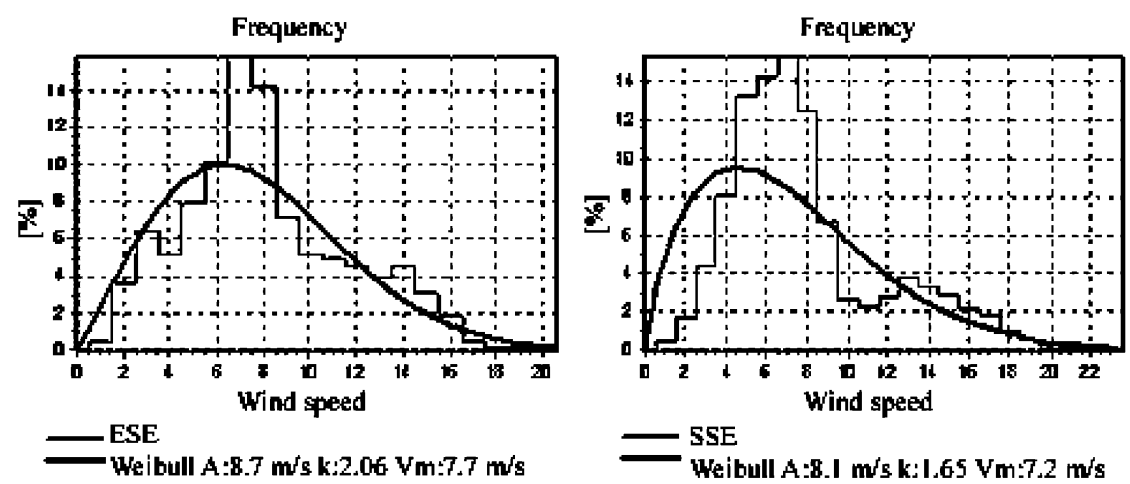

Fig. 7. Weibull and turbulence histograms of the easterly six sectors at $10 \mathrm{~m}$ height.

Fig. 11. But, Fig. 12 which depicts evaluation of the data measured at $30 \mathrm{~m}$ height, shows very low turbulence in north direction. These two contradictory results are not unexpected, because of surface roughness influence at $10 \mathrm{~m}$ height. Measurements at $30 \mathrm{~m}$ height show turbulence-free characteristic which should be considered as the more realistic graph of the site. Complex terrain and the hills with different heights cause turbulence at other sectors. 
Frequency

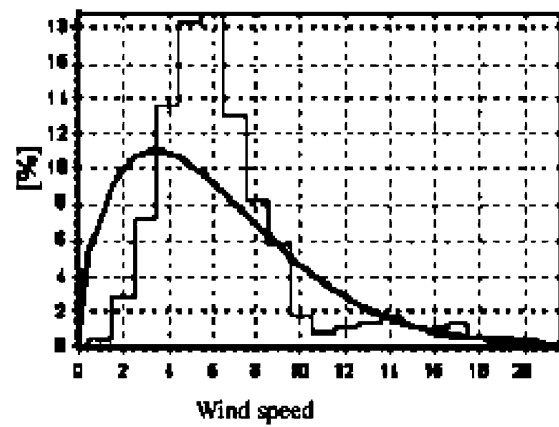

$-\mathbf{5}$

Weibull A.6.8 m/s k:1.54 Vmt6.1 m/s

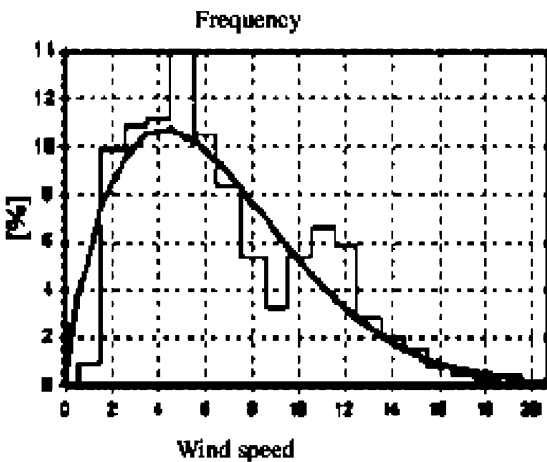

WSW

Weibull A:72 m/s k:1.6.8 Vmt6.5 m/s

Frequency

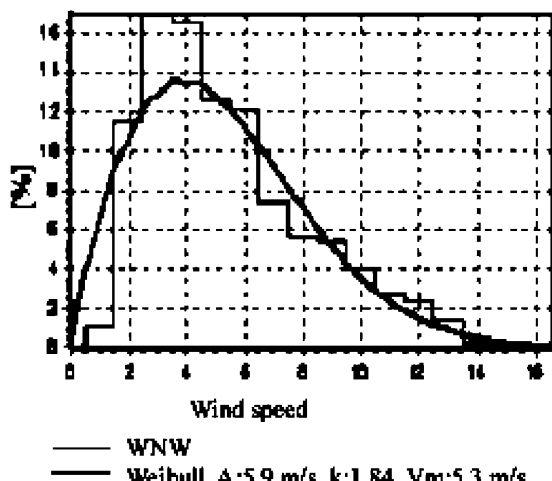

Weibull A $5.9 \mathrm{~m} / \mathrm{s} \quad \mathrm{k}: \mathrm{l} .84 \mathrm{Vm}: 5.3 \mathrm{~m} / \mathrm{s}$
Frequency

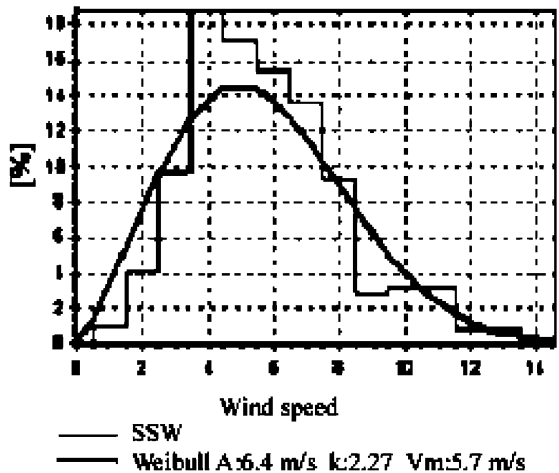

Frequency

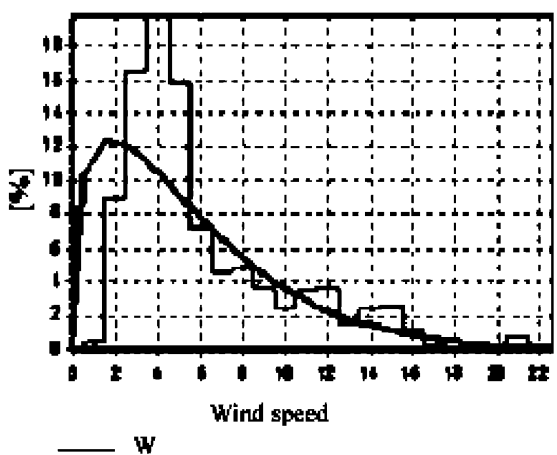

Weibull A.6.0 m/s k:1.2g Vm.5.5 m/s

Frequency

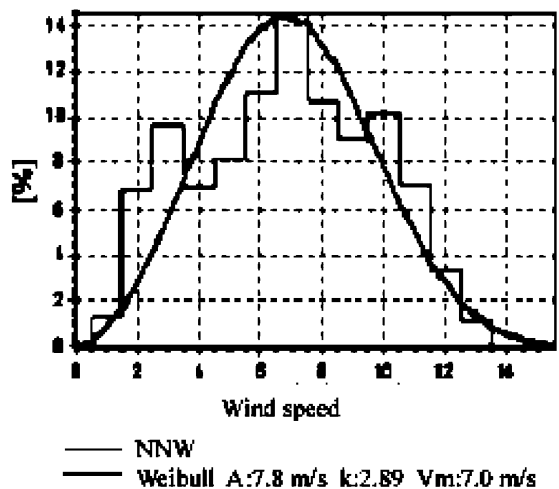

Fig. 8. Weibull and turbulence histograms of the westerly six sectors at $10 \mathrm{~m}$ height. 


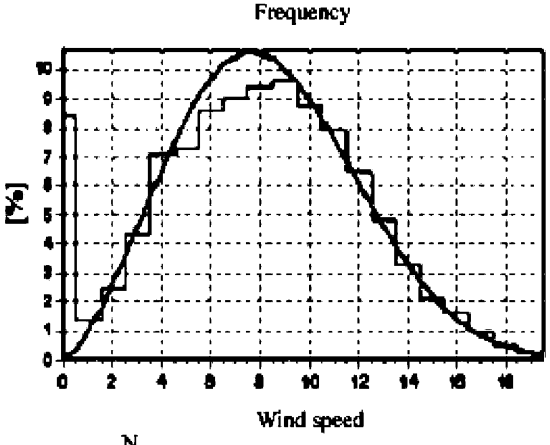

Weibull A.9.4 m/s k:2.47 Vm:8.3 m/s

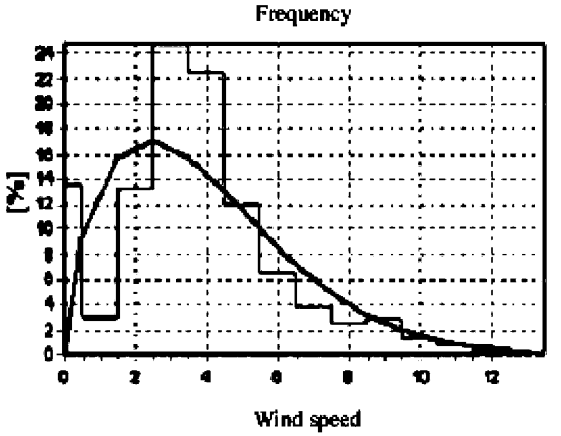

ENE

Weibull A:4.4 $\mathrm{m} / \mathrm{s}$ k:1.60 Vm:4.0 $\mathrm{m} / \mathrm{s}$

Frequency

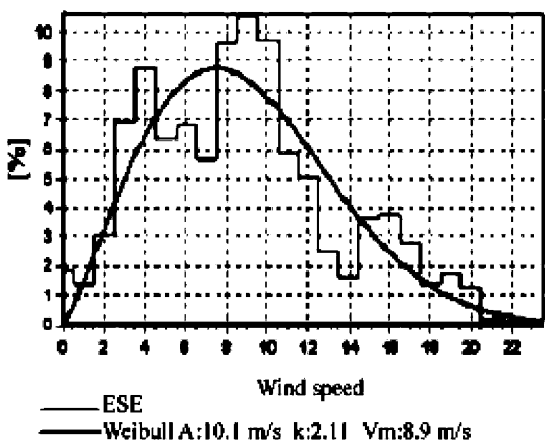

Frequency

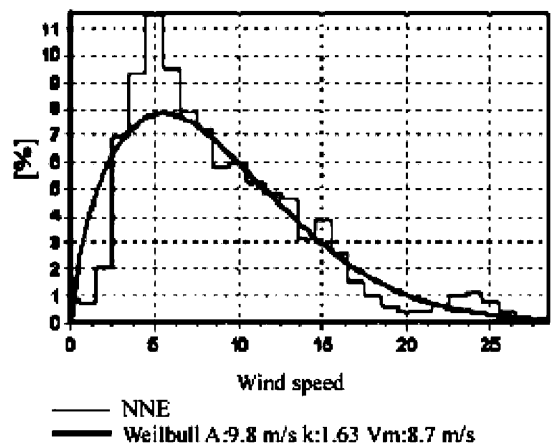

Frequency

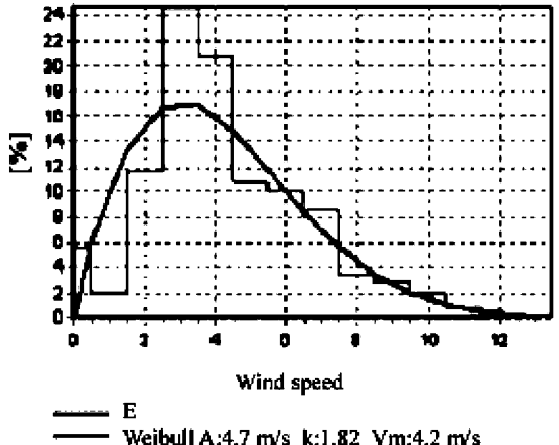

Frequency

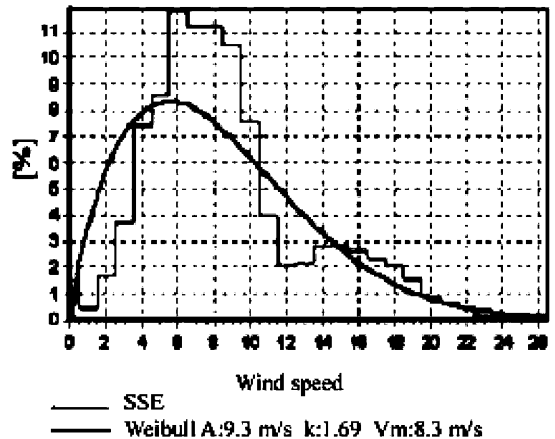

Fig. 9. Weibull and turbulence histograms of the easterly six sectors at $30 \mathrm{~m}$ height.

\subsection{Mean wind speed map}

Collected data have been evaluated by 'windPro' and 'WAsP' softwares to create mean wind speed map of the campus. Roughness map of the measurement site with $20 \mathrm{~km}$ radius and orography map with $5 \mathrm{~km}$ radius have been used by 'WAsP' to 


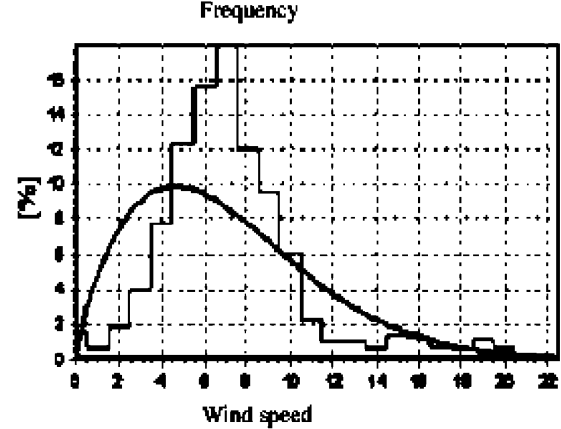

$-5$

Weibull A:7.9 m/s k: $1.69 \mathrm{Vm}: 7.0 \mathrm{~m} / \mathrm{s}$

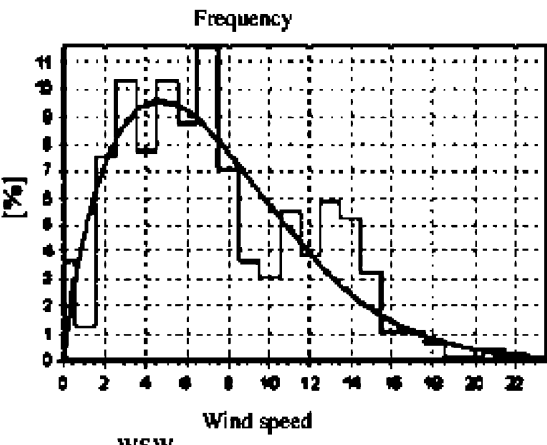

WSW

Weibull A:8.I m/s k:1.67 Vm:7.2 m/s

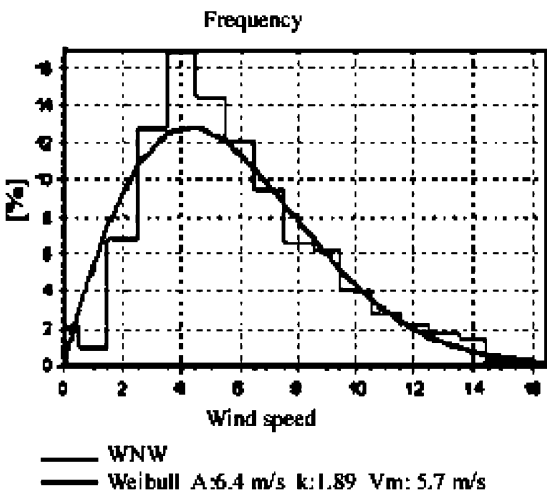

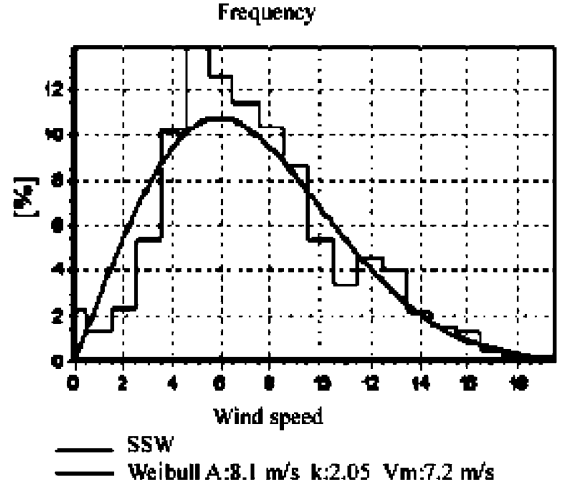

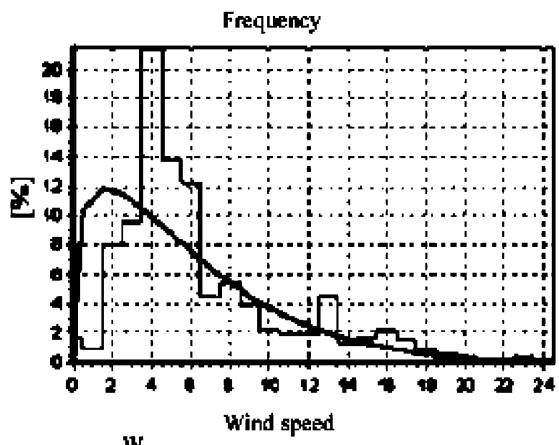

W

Weibull A.6.3 m/s k:1.24 V/m: $5.9 \mathrm{~m} / \mathrm{s}$

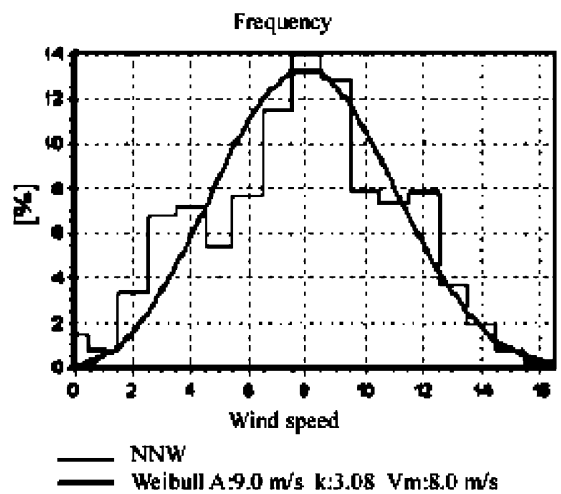

Fig. 10. Weibull and turbulence histograms of the westerly six sectors at $30 \mathrm{~m}$ height.

predict mean speeds of other locations of the campus. Created map covers 177.7 $\mathrm{km}^{2}$ area with a resolution of $50 \mathrm{~m}$. Fig. 13 shows mean wind speed zones. 


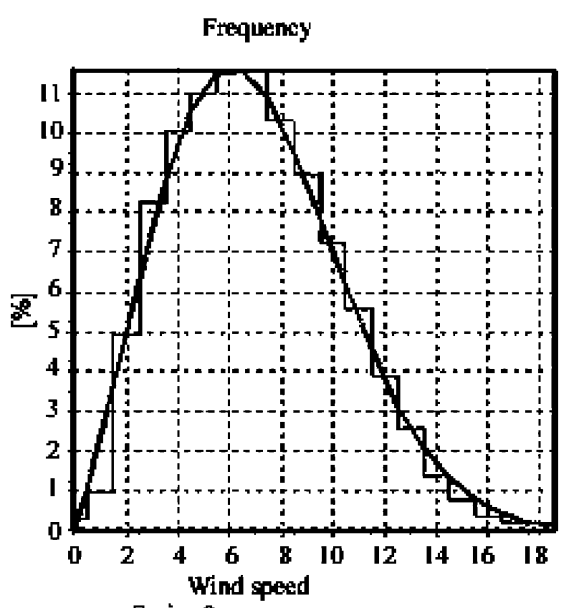

Series 0

Weibull A.:7.9 m/s $\mathrm{k} 2.23 \mathrm{Vm}=7.0 \mathrm{~m} / \mathrm{s}$

Turbuknce

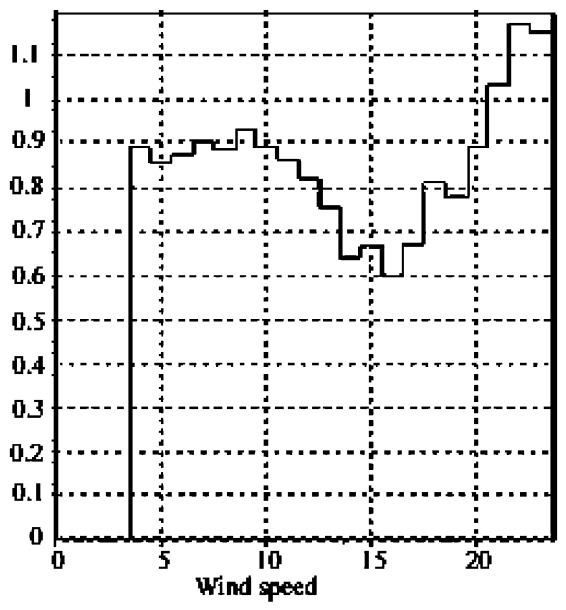

Frequency

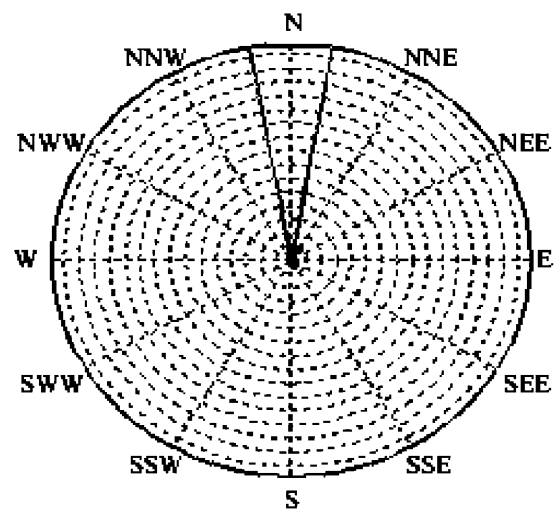

Turbulence

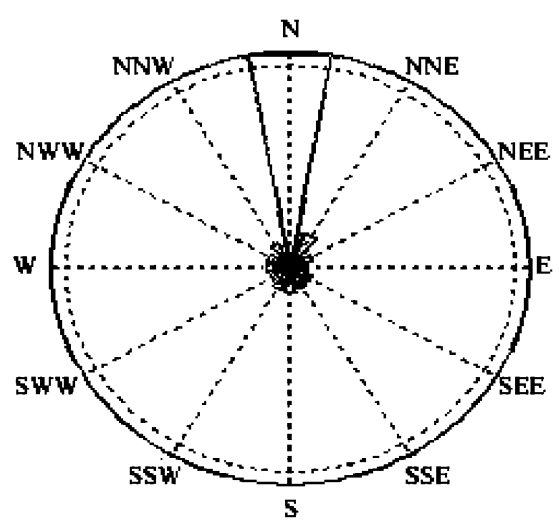

Fig. 11. Wind rose and histograms of wind speed and turbulence at $10 \mathrm{~m}$ height.

\section{Conclusion}

The study presented here is an attempt to promote wind energy in Turkey and to bridge the gap in order to create prospective Turkish Wind Atlas. A standard wind measurement mast was erected on the campus in order to investigate wind characteristics. 'WASP' and 'WindPRO' softwares used for evaluation of measured data were generally representative of the area. Weibull approximation was found to be better than that of Rayleigh model. Turbulence-free character of the wind, especially at prevailing direction, was one of the most important results of the study. The result derived from this study encourages the utilization of wind energy potential on the 


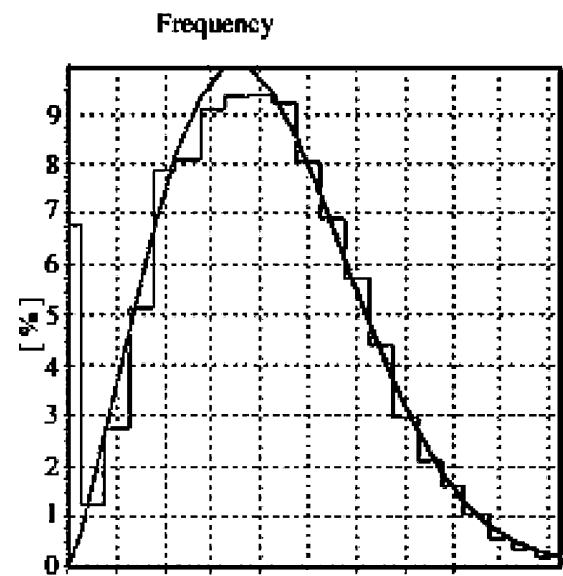

Series 0

Weibull A.9.2 m/s k:2.21 Vm:8.1 m/s

Turbulence

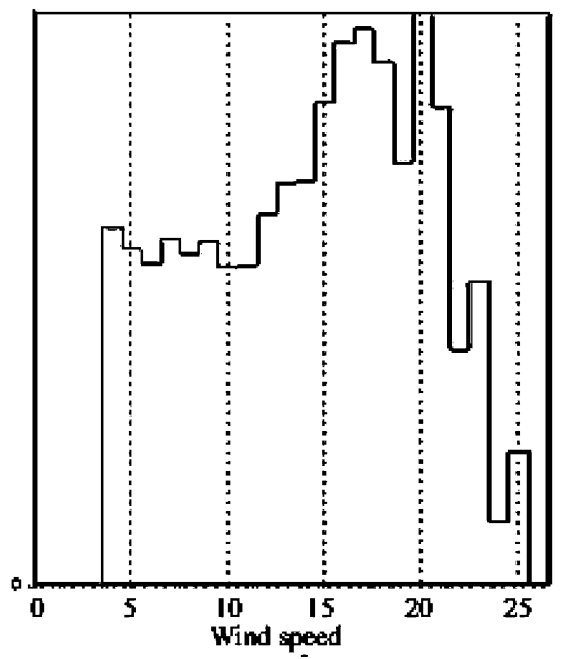

Frequency

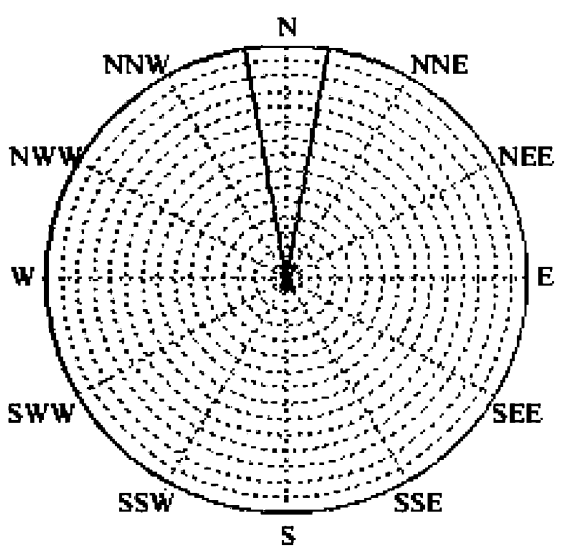

Turbulence

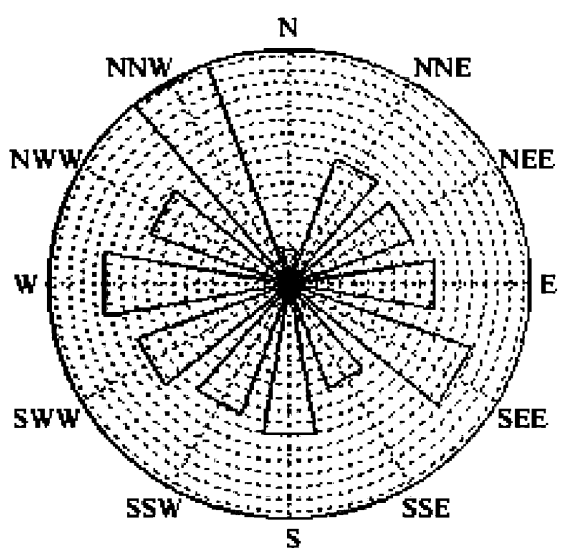

Fig. 12. Wind rose and histograms of wind speed and turbulence at $30 \mathrm{~m}$ height.

Izmir Institute of Technology campus area. The presence of high wind potential in the area is explicitly demonstrated.

\section{Acknowledgements}

The authors gratefully acknowledge the Izmir Institute of Technology Research Fund for the financial support of the present study through project AFP-2001 MÜH 01. 


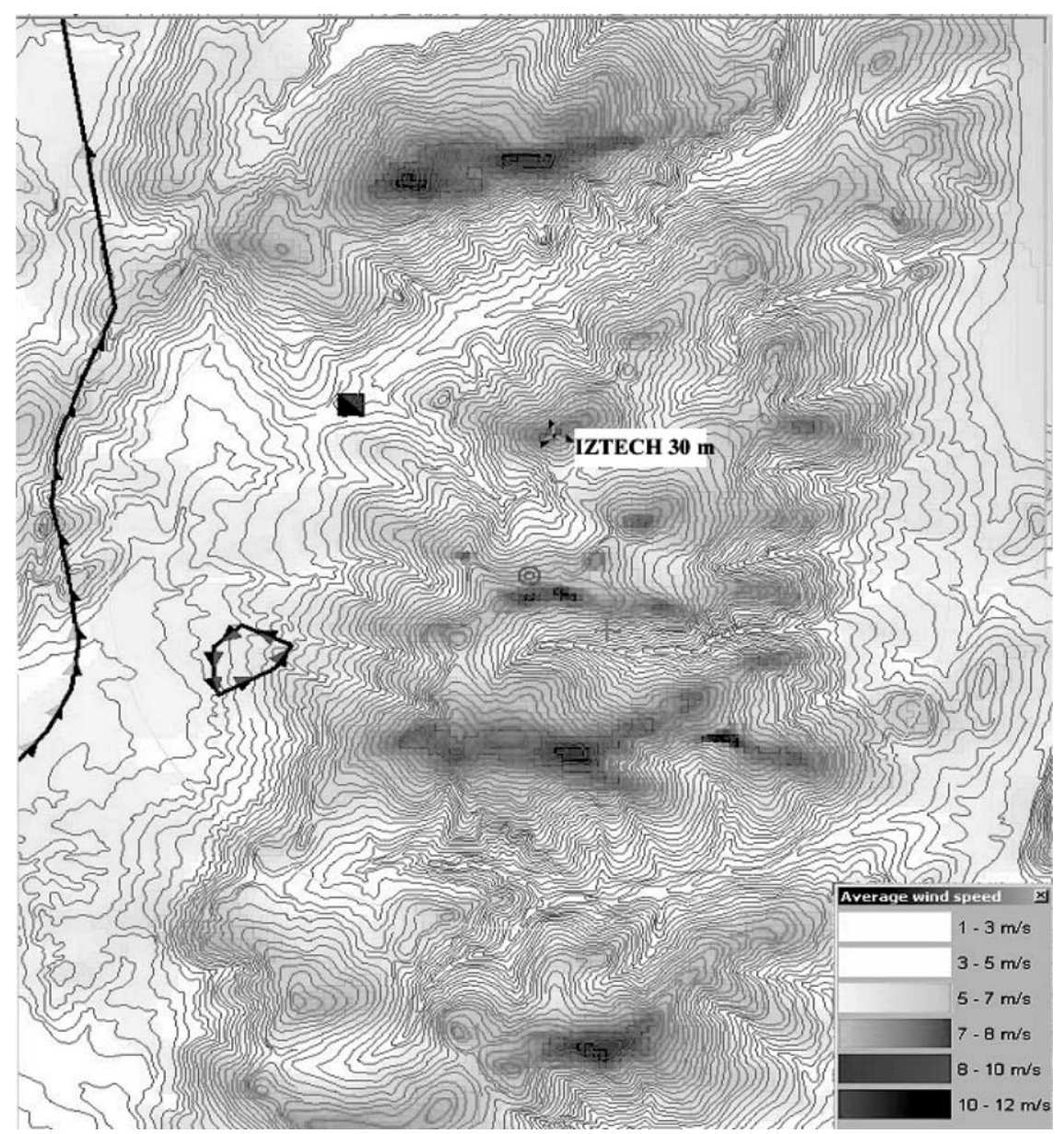

Fig. 13. Average mean speed map of the area.

\section{References}

[1] Troen I, Petersen EL. European wind atlas. Riso National Laboratory; 1989.

[2] Tolun S, Menteş S, Aslan Z, Yükselen MA. The wind energy potential of Gökçeada in the northern Aegean Sea. Renew Energ 1995;6(7):679-85.

[3] Incecik S, Erdoğmuş F. An investigation of the wind power potential on the western coast of Anatolia. Renew Energ 1995;6(7):863-5.

[4] Şen Z, Şahin AD. Regional assessment of wind power in western Turkey by the cumulative semivariogram method. Renew Energ 1997;12(2):169-77.

[5] Türksoy F. Investigation of wind power potential at Bozcaada, Turkey. Renew Energ 1995;6(8):917-23.

[6] Dündar C, Inan D. Investigation of wind energy application possibilities for a specific island (Bozcaada) in Turkey. Proceedings of World Renewable Energy Conference, (Ed. A. Sayigh) Denver, CO, 1996 p. 822-826.

[7] AWS Scientific Inc. Wind resource assessment handbook. National Renewable Energy Laboratory; 1997. 